\title{
Bore and Well Water Quality Studies in the Tarkwa-Nsuaem Municipality and Prestea-Huni-Valley District, SW Ghana*
}

\author{
I. F. Quansah and R. K. Amankwah
}

Quansah, I. F. and Amankwah, R. K. (2010), "Bore and Well Water Quality Studies in the Tarkwa-Nsuaem Municipality and Prestea-Huni-Valley District, SW Ghana", Ghana Mining Journal, Vol. 12, pp. 49 - 57.

\begin{abstract}
The quality of bore and well water within the Tarkwa-Nsuaem Municipality and Prestea-Huni-Valley District has been studied. The major cationic pollutants with concentrations above the WHO standards were iron, molybdenum, lead, mercury and manganese. High nitrate levels were found in boreholes at Akoon and Brenu Akyim which are communities close to active large scale mines where nitrates are major constituents of the explosives utilised. The study revealed that due to high microbial contamination, wells and boreholes at Tarkwa Community Centre, GAG Mile 7, Teberebie Roadside, Samahu Quarters, Dumasi, Abekoase, and Prestea Anyinam will require shock chlorination. Such a step can potentially reduce the numerous domestic water related sicknesses recorded in the investigation. Hydrochemical modelling using PHREEQC software indicated that some minerals had high saturation indices with the highest being goethite, hematite and ferric hydroxide at $7.38,16.78$ and 1.38 respectively within a borehole at Dumasi. The relatively high saturation indices of the iron oxides and hydroxides in the Dumasi samples explain the reddish brown precipitate formed when the samples are allowed to stand for a while. The results demonstrate that geological, mining and non-mining community related activities contribute to the water quality within the study area.
\end{abstract}

\section{Introduction}

Water that is used for domestic application should satisfy some basic requirements to ensure that the communities that utilize such waters are not put at risk. The conditions include physical characteristics such as colour, turbidity and total suspended solids; biological features such as the population of microorganisms and chemical parameters such as cation and anion concentrations and dissolved oxygen content (Shaw, 1994; and Holmes, 1996). Domestic water may be pipe borne, surface or groundwater.

Groundwater wells are "engineered holes in the ground" that are constructed to access water that fills the cracks and pores of rocks in the earth's upper crust (Henry and Heinke, 1996; Todd, 1980). For many communities, groundwater is a major source of domestic water as pipe borne water may not be available to all inhabitants. Unfortunately, groundwater in many communities is not tested consistently to ensure that it is safe for domestic application. Thus, in communities having challenges with waste disposal and where run-offs and contamination are common, the quality of groundwater may be compromised.

In the Tarkwa-Nsuaem Municipality pipe borne water is supplied from Bonsa River but this is not enough to meet the demand of the area's large population. Kuma and Ewusi (2009) reported that water produced by the Ghana Water Company reduced from 76 litres/day/person in 1987, to 40 litres/day/person in 2008. Consequently, over $40 \%$ of the people depend on water from boreholes and hand-dug wells. Rainfall in the study area is high with mean annual value of $1933 \mathrm{~mm}$ and range $984 \mathrm{~mm}$ to $2414 \mathrm{~mm}$ (Al-Hassan, 2007). Thus, the water table in this area is high and the groundwater has a high risk of pollution or contamination. In addition refuse dumps, man holes and wells in the Tarkwa area are sited in close proximity without a good study of ground water movement. Thus the possibility of migration of faecal effluents from such pits into the ground water is quite high. More importantly, since TarkwaNsuaem and Prestea-Huni-Valley are both major mining areas, there is high possibility of migration of sulfides and cyanide rich waters from tailings impoundments into the ground leading to contamination with heavy and toxic metals like mercury, lead, iron and manganese among others.

In the study area, there is no state agency that consistently monitors the quality of bore and well water. According to Kuma and Ewusi (2009) only 24 out of more than 300 wells in Tarkwa have been chemically and biologically analysed. Some studies on the impact of mining activities on water quality in the two study areas primarily focused on heavy metals or trace elements such as mercury (Adimado and Baah, 2002; Bonzongo et al., 2003; Kuma, 2004; Momade and Darabor, 2007; Kortatsi, 2004; Asklund and Eldvall, 2005; Donkor et al.,

\footnotetext{
* Manuscript received September 1, 2010

Revised version accepted November 2, 2010
} 
2006; Asante et al., 2007; Sandaare, 2008).

Communities can, however, only employ safety measures for domestic water from boreholes and wells when a complete examination of possible pollutants and physical parameters is conducted. Such a study will portray correctly the impact of both mining and non-mining community activities on the bore/well water supply. In this investigation, water quality in the Tarkwa-Nsuaem Municipality and the Prestea-Huni-Valley District was studied to determine the level of contamination of bore/well water and the influence of mining and non-mining community related activities on contaminants present. Hydrochemical modeling of the data was done using the PHREEQC software.

\section{Study Area}

Together the Tarkwa-Nsuaem Municipality and Prestea-Huni-Valley District were formally known as the Wassa-West District and are located in the south-western part of the Western Region of Ghana. Climatically, the district lies within the south-western equatorial zone and is marked by double maximum rainfall starting from March to September. The area experiences one of the heaviest and most frequent rainfalls in Ghana. The annual mean rainfall is $1878.3 \mathrm{~mm}$ and a fairly uniform temperature ranging between $26^{\circ} \mathrm{C}$ in August and $30^{\circ} \mathrm{C}$ in March is common within the area. Relative humidity is generally high throughout the year between $75 \%$ and $90 \%$ (Anon, 2008). The Tarkwa region is also part of an extensive drainage basin known as the Ankobra basin (Fig 1) comprising the Ankobra River and its tributaries and the Bonsa sub-basin comprising of the Bonsa River and its tributaries.

The Birimian and Tarkwaian gold bearing systems are the main rock systems in the study area. The Birimian is known for its sulphur and arsenic rich minerals such as arsenopyrite while the minerals commonly found in the Tarkwaian are chlorites, chloritoids, calcites, sericites, quartz and limonites (Kesse, 1985). Due to the gold bearing minerals, the area is home to five large-scale surface mines; four gold and one manganese mine. The major environmental setbacks associated with their operations include land degradation, cyanide spillage, acid mine drainage and dust from blasting operations and haul roads. In addition, there are hundreds of artisanal and small-scale gold miners who use mercury in their operations. Several other service companies that deal with explosives, acids and persistent organic chemicals are also present.

The issue of sanitation in the study area, especially the big towns such as Tarkwa and Prestea, requires improvement. With continuous influx of people into the District to do business, thousands of ton-

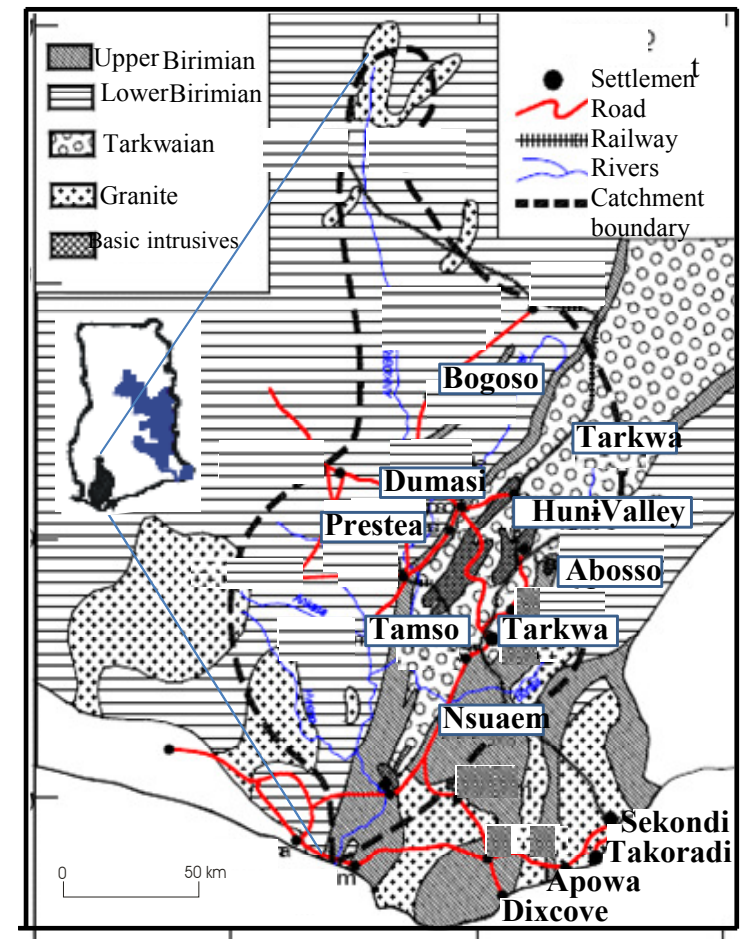

Fig. 1 Geological Map of the Ankobra Basin (After Kortatsi, 2004)

nes of solid and liquid waste are generated (Anon, 2008). Unfortunately, the District lacks liquid waste treatment plant hence disposal is done mostly into drains, streams and rivers thus, heightening the possibility of ground water pollution.

\section{Field and Experimental Investigations}

\subsection{Sampling}

The sampling plan was drawn in consultation with the Environmental Protection Agency (EPA) District Office and Water and Sanitation Departments of the then Wassa-West District now comprising the Tarkwa-Nsuaem Municipality and PresteaHuni-Valley District. The statistics, location and quantity of wells in the municipality were taken into consideration to ensure a fairly distributed sampling program for the municipal area. Forty one (41) boreholes and 20 wells within the Ankobra basin in 60 communities of the 13 main towns were sampled.

Water samples were collected, during the dry and wet seasons of 2008 (March to December) from both hand-dug wells and bore-holes used for domestic purposes. At each sampling site, three samples were collected for bacteria, cations and anions analyses. Samples for bacteria analysis were collected in $100 \mathrm{ml}$ sterilised bottles and, where sample analysis was to be delayed by one hour or 
more, immediately stored at $4^{\circ} \mathrm{C}$. The other samples were collected in $1000 \mathrm{ml}$ acid-washed highdensity linear polyethylene (HDPE) bottles with strict adherence to sampling protocol described by Claasen (1982) and Barcelona et al. (1985).

\subsection{Insitu Physical Measurements}

On-site analyses of $\mathrm{pH}$ and temperature; Total Dissolved Solids (TDS), electrical conductivity and turbidity were conducted using the HJM Electronics model C6-M, ML (Misura Line) $1010 \mathrm{pH}$ Meter and Hach DR 890 respectively.

\subsection{Analysis of Chemical Constituents}

Atomic absorption spectrophotometry (Varian AA240) was used to analyse for heavy metals ( $\mathrm{Mn}, \mathrm{Fe}, \mathrm{Pb}, \mathrm{Hg}, \mathrm{Cr}, \mathrm{Cu}, \mathrm{Zn}$ and $\mathrm{Mo}$ ). A Hach Smart 2 Calorimeter (Lamotte Company, USA) was used to analyse for the nitrates, nitrites, phosphates and ammonia. The Hach DR / 890, with appropriate reagents as described in the DR/890 Datalogging Colorimeter Handbook (Anon, 1999) was employed to test for free and total chlorine, cyanide, sulfates, and dissolved silica.

\subsection{Bacterial Analysis}

A 3M petrifilm Escherichia coli, coliform and aerobic count plates from 3M Microbiology, USA, were used for total bacteria, total coliform and $E$. coli tests. This sample-ready-culture-medium system contains violet red bile nutrients, a cold water soluble gelling agent, an indicator of glucuronidase activity,5-bromo-4-chloro-3-indolyl-b-Dgluculonide and a tetrazonium indicator that facilitates colony enumeration.

\subsection{Hydrochemical Modelling}

Hydrochemical modeling of data from selected areas were run on PHREEQC software to establish the possible minerals contributing to the constituents in the ground water. Assumptions made in the modeling process are that the dissolved species are in chemical equilibrium, and that the initial parameters like temperature and pressure would not change. Measured ions were used as input parameters and it was assumed that their state will not change in the course of the reaction.

\section{Results and Discussion}

In this study, samples were taken in both the wet and dry seasons of 2008 and for most tests, a marginal difference, which when computed gave a relative error of between \pm 0.01 and \pm 0.11 , was observed between the dry and wet period sample test results. The only result that showed wide deviation between dry and wet seasons is the $E$ Coli in Samahu well, which for four samples, the $95 \%$ confidence interval was $26 \pm 10 \mathrm{MPN}$ cfu/100ml.
All values obtained were compared with the World Health Organization (WHO) guideline levels (Anon, 1996; Anon, 2004).

\subsection{Analysis of Chemical Constituents}

\subsubsection{Non-metals}

The investigations indicated that in all the 61 units sampled nitrites and phosphates were common in the wells. However, their concentrations in addition to that of cyanide, sulfates and chlorides were all within the WHO standards of $0.2 \mathrm{mg} / 1,5 \mathrm{mg} / 1$, $0.07 \mathrm{mg} / \mathrm{l} 250 \mathrm{mg} / \mathrm{l}$ and $250 \mathrm{mg} / \mathrm{l}$ respectively, acceptable for drinking water.

High concentrations of nitrate, exceeding the WHO guideline value of $50 \mathrm{mg} / \mathrm{l}$ were detected in both the Akoon Green compound borehole $(61 \mathrm{mg} /$ 1) and the Brenu Akyim well (59 mg/l). The high nitrate values could be attributed to migration of fecal matter into the ground water, where bacteria convert nitrites to nitrates under anaerobic conditions. It could also be agricultural run-offs or the residue of explosives.

Despite the nitrate levels, no fecal contamination was observed. Akoon and Brenu Akyim are close to the blasting sites of Gold Fields Ghana Company Limited, and Ghana Manganese Company respectively which suggests that the high nitrate levels could largely be due to chemicals such as ammonium nitrate used for rock fragmentation. Previous studies (Sandaare, 2008; Asklund and Eldvall, 2005) showed high nitrate concentrations in boreholes at Akoon and wells from the nearby communities Huniso and Abekoase.

\subsubsection{Metals and Metalloids}

The results of the investigation show that all the wells and boreholes had concentrations of $\mathrm{Cu}, \mathrm{Cr}$, As and $\mathrm{Zn}$ below the WHO threshold values of 2.0 $\mathrm{mg} / 1,0.05 \mathrm{mg} / 1,0.01 \mathrm{mg} / \mathrm{l}$ and $3.0 \mathrm{mg} / 1 \mathrm{respec}-$ tively, for potable water. For arsenic, the highest value of $0.005 \mathrm{mg} / \mathrm{l}$ was observed at the Dumasi Market and this may be a natural occurrence in the ground water or due to oxidation of arsenopyrite which is associated with the rocks of the Prestea area (Kesse, 1985).

Studies by Kuma (2004), Kortatsi (2004), Asklund and Eldvall (2005), and Sandaare (2008), which focused on Tarkwa and its environs, indicated some level of heavy metal contamination in water in the Tarkwa area which generally compares well with test results of this research for boreholes within the Tarkwa town.

Iron concentrations were found to exceed the WHO recommended limit of $0.5 \mathrm{mg} / 1$ in Simpa, Dadwen, Dompim, Odumase, Aboso, and Anyinase boreholes (Fig. 2). The highest concentration of $8.28 \mathrm{mg} / \mathrm{l}$ was observed in Dumasi samples 
Table 1 Some parameters for the Wells (marked W) and Boreholes Studied. World Health Organization (WHO) guidelines are listed at the top of the table. ${ }^{\mathrm{a}}$ Total dissolved solids, ${ }^{\mathrm{b}}$ Total suspended sol ids, ${ }^{\mathrm{c} C o n d u c t i v i t y,}{ }^{\mathrm{d}}$ Turbidity in Nephelometric Turbidity Units

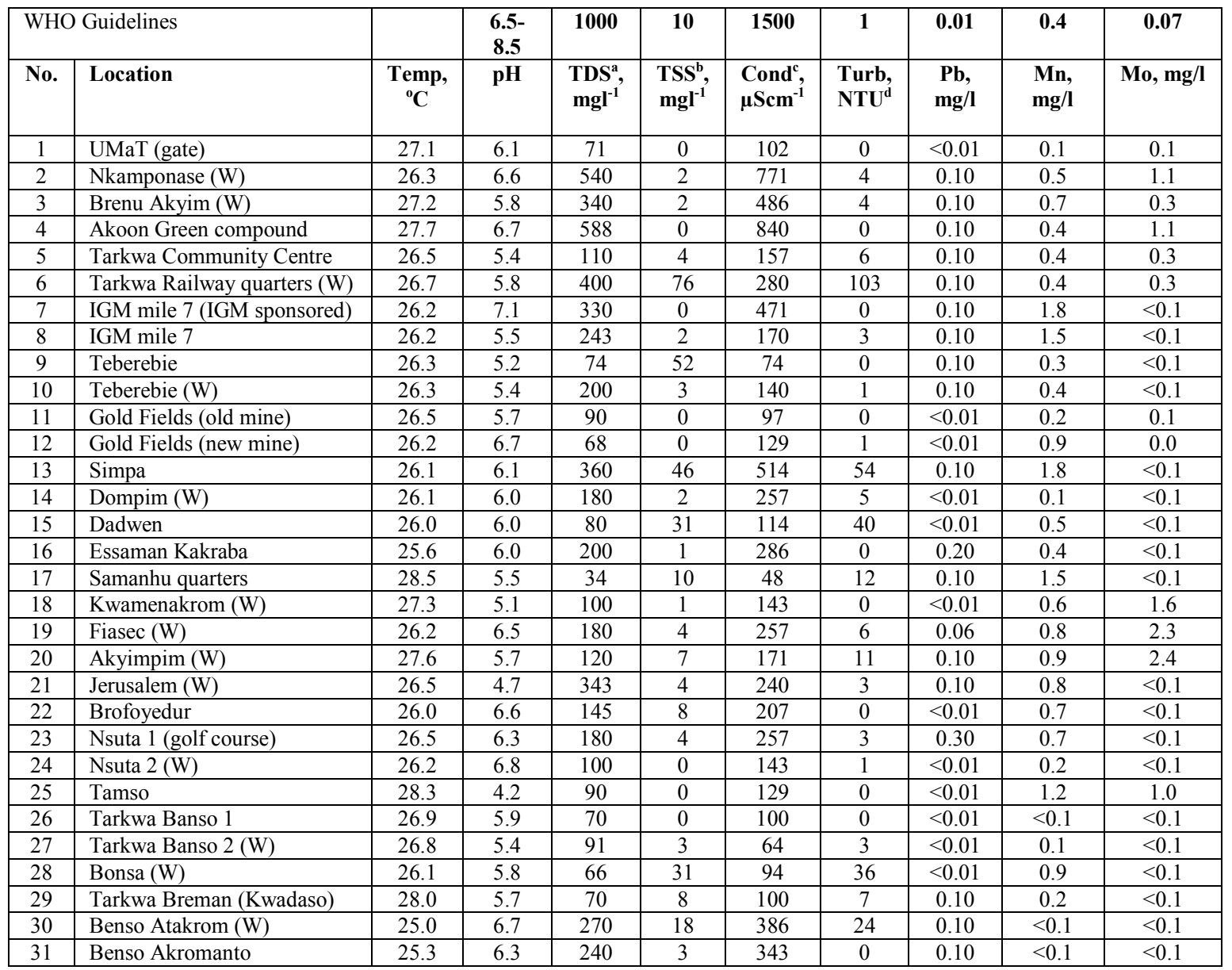

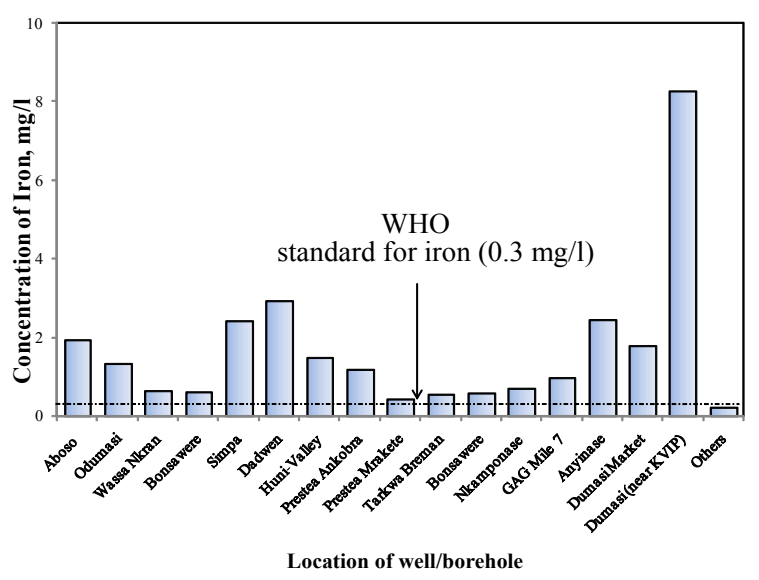

Fig. 2 Iron Concentration in Selected Boreholes and Wells in the Tarkwa Municipality and Prestea Huni Valley District

which also recorded the highest turbidity and TSS among the bore-hole samples (Table 1). Dumasi Market and Dadwen samples turned blue black upon contact with starchy foods such as cassava and plantain. Thirty minutes after sampling reddish settlement was observed at the base of the sample bottles of the Dumasi Market and Dadwen samples, which physically suggest high iron content.

Seven sample points had mercury concentrations much higher than the WHO guideline value of $0.001 \mathrm{mg} / \mathrm{l}$ for domestic use. These are Fiaseman Senior High School (Fiasec) (0.06 mg/l), Kwamenakrom $(0.06 \mathrm{mg} / \mathrm{l})$, Akyimpim $(0.04 \mathrm{mg} / \mathrm{l})$ and Akoon Green compound $(0.04 \mathrm{mg} / \mathrm{l})$. The rest are Samahu (0.02 mg/l), Prestea Ankobra $(0.01 \mathrm{mg} / \mathrm{l})$ and Tarkwa Community Centre $(0.02 \mathrm{mg} / \mathrm{l})$. The Kwamenakrom and Akoon wells are close to artisanal small-scale mining (galamsey) sites, where mercury amalgamation method of gold extraction is used regularly. Previous studies by Kortatsi (2004) recorded $0.026 \mathrm{mg} / \mathrm{l}$ at Odumasi and 0.025 $\mathrm{mg} / \mathrm{l}$ at Prestea as the highest values. These values are low compared to the $0.06 \mathrm{mg} / \mathrm{l}$ and $0.04 \mathrm{mg} / \mathrm{l}$ values obtained in this study for the earlier mentioned sites. The Prestea underground mining operations collapsed in 2004 rendering about two thousand people jobless. Majority of these unemployed folks moved to the Tarkwa area to look for jobs, most of which did not exist. Consequently 
Table 2 Some Parameters for the Wells (marked W) and Boreholes Studied. World Health Organization (WHO) Guidelines are listed at the top of the Table. ${ }^{a}$ Total Dissolved Solids, ${ }^{b}$ Total Suspended Sol ids, ${ }^{\mathrm{c} C o n d u c t i v i t y,}{ }^{\mathrm{d}}$ Turbidity in Nephelometric Turbidity Units

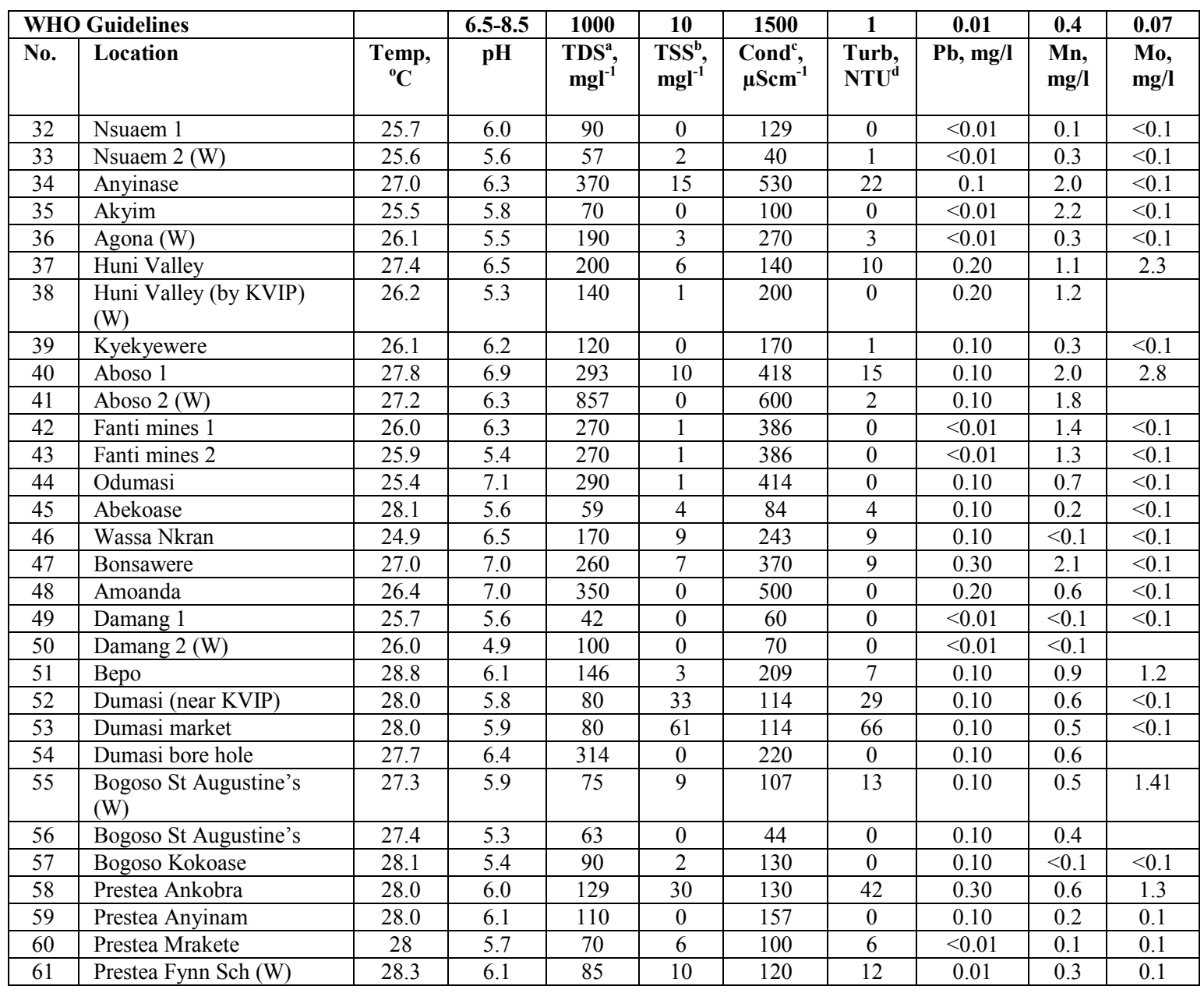

most of the people settled on small-scale mining. This has led to increased small-scale gold mining with attendant mercury amalgamation activities in the environs of Tarkwa, where the four communities mentioned above can be found.

Water in wells at Abosso, Huni-Valley, Prestea Ankobra and Bepo market had high molybdenum concentrations of $2.8 \mathrm{mg} / 1,2.3 \mathrm{mg} / 1,1.3 \mathrm{mg} / \mathrm{l}$ and $1.2 \mathrm{mg} / \mathrm{l}$ respectively though the WHO standard is $0.07 \mathrm{mg} / \mathrm{l}$ (Table 1). The $\mathrm{pH}$ of waters in these areas were $6.3,5.3,6.0$ and 6.1 respectively and the relatively low $\mathrm{pH}$, below WHO standards for drinking water (6.5), may account for the dissolution of molybdenum which occurs under acidic conditions. All other samples were generally of acceptable molybdenum concentrations. In the study area, molybdenum may occur as a sulphide $\left(\mathrm{MoS}_{2}\right)$ in the Birimian or as wulfenite $\left(\mathrm{PbMoO}_{4}\right)$ and powerllite $\left(\mathrm{CaMoO}_{4}\right)$ in the oxide zones of the Tarkwaian (Kesse, 1985) and these may account for the presence of molybdenum in some samples. Asante et al. (2007) also mentioned molybdenum as a concern in drinking water and further investi- gations may be required.

Lead concentrations averaged 0.05 to $0.25 \mathrm{mg} \mathrm{l}^{-1}$ (Tables 1 and 2) and $56 \%$ of wells and boreholes analysed for lead had values greater than WHO guideline value of $0.01 \mathrm{mg} / \mathrm{l}$. (Anon, 2004). Prestea Ankobra, Bonsawere and Nsuta Golf Course recorded the highest $(0.30 \mathrm{mg} / \mathrm{l})$ cases of $\mathrm{Pb}$ levels. Both of $\mathrm{Pb}$ and $\mathrm{Mo}$ are known to cause mental development problems in children and young adults (Chappell et al., 1979) and the high levels are a source of worry. Golow and Kwaansaansah (1994) and Golow and Laryea (1994) also reported high lead levels in water samples in the Tarkwa area. Relative to previous work done by Kortatsi (2004) in the Tarkwa-Nsuaem and Prestea -Huni-Valley areas this study showed generally increased lead contamination in the ground waters. In addition to possible geological influence, one anthropogenic source may be the indiscriminate disposal of spent dry cell batteries by small-scale miners who use them for lighting and other pit operations.

About $50 \%$ of wells and boreholes had Mn levels 
above the WHO guideline value of $0.4 \mathrm{mg} \mathrm{l}^{-1}$, with three Anyinase, Akyim and Bonsawere sites having manganese concentration above $2.0 \mathrm{mg} 1^{-1}$. These sites are close to the manganese mine at Nsuta and the high values may be due to dissolution and migration of manganese. Two other sites, Simpa and Aboso also had manganese concentrations of $1.8 \mathrm{mg} / \mathrm{l}$ and are also close to the manganese deposits. In addition, manganese waste was used in road construction in areas close to Simpa. The dangers of manganese in drinking water has been studied previously (Bamforth et al., 2006; Hafeman et al., 2007) and it may be necessary for surveillance to be mounted and remedial measures put in place to reduce the level of manganese.

\subsection{Bacteria Analysis}

Fig. 3 and 4 illustrate the total bacteria, coliform and $E$ coli in the units tested. Except for the one at Benso Atakrom, all the wells tested had at least one of these microbial counts in excess of the standards ( $2 \mathrm{cfu}$, coliform; $0 \mathrm{cfu}, E$ coli). In addition, seven of the boreholes surveyed are not fit for drinking in view of the high bacteria content. These bore-holes are at: Tarkwa Community Centre, GAG Mile 7 No 2, Teberebie Roadside, Samahu Quarters, Dumasi Bore-hole pipe, Abekoase, and Prestea Anyinam. Previous studies done by Akabzaa and Darimani (2001) also showed heavy fecal pollution of GAG Mile 7 well and Teberebie borehole.

The well at the Tarkwa Railway Quarters and borehole at Samahu quarters showed high values of both $E$ coli and coliform bacteria. Contamination with such microbial species is primarily attributed to human and/or animal waste seepage. Indeed the borehole at the Samahu quarters was sited about $20 \mathrm{~m}$ from a septic tank and there appears to be migration of fecal material from the tank into the borehole.

Proper sanitation and waste treatment facilities in Ghana have always created concern for the population. In some cases, villagers are taught to boil the water to kill live bacteria in their drinking water, however, boiling water concentrates metals and other pollutants. In areas, like Samahu and Abekoase where molybdenum and lead are already at high concentrations, other options for reducing the bacterial contamination could be investigated. The results show that free chlorine and total chlorine concentrations were less than $0.1 \mathrm{mg} / \mathrm{l}$ in all the hand dug wells and boreholes and this low value may account for the high microbial populations. Thus, shock chlorination could be adopted.

Fig. 5 and 6 illustrate statistically the total cases of bacteria related diseases in the Tarkwa-Nsuaem municipal area and Prestea-Huni-Valley Districts. From 2004 to 2008, the incidence of di-

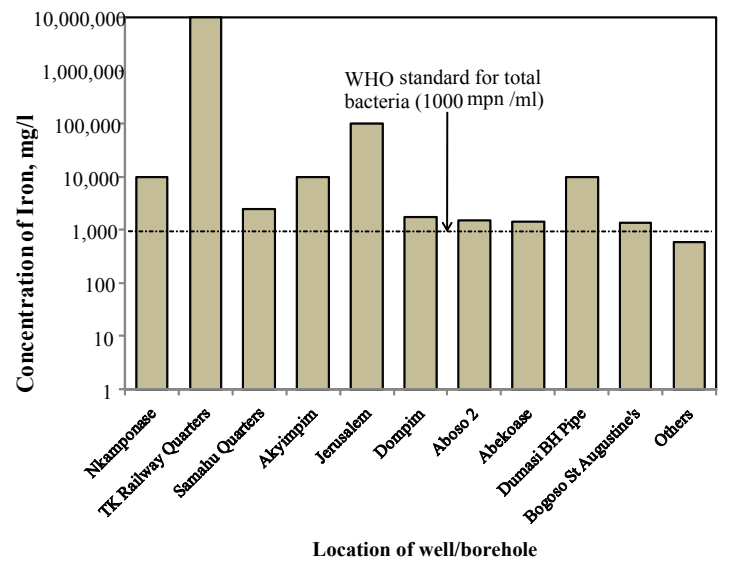

Fig. 3 Total Bacteria in Selected Boreholes and Wells in the Tarkwa Nsuaem Municipal ity and Prestea Huni Valley District

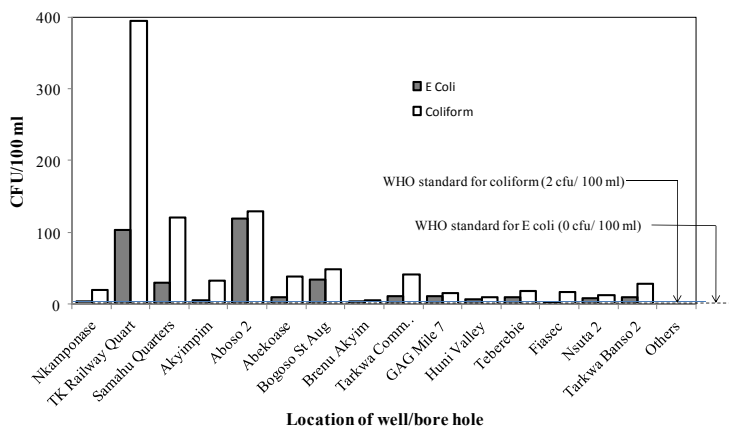

Fig. 4 Coliform and $E$ coli in Selected Boreholes and wells in the Tarkwa Nsuaem Municipality and Prestea Huni Valley District

arrhea, bacteria related diseases and water borne disease related deaths increased by more than $200 \%$. Population growth rate in both areas is 2.97 $\%$ per year hence the increase in the number of water quality related deaths cannot be attributed to population increase. Possible increases in waste dumps, indiscriminate dumping and inefficient liquid waste disposal may have consequently increased the fecal coliform wash down into the water bodies.

\subsection{Physical and other Chemical Measurements}

Parameters such as total suspended solids, conductivity and hardness may not have major health concerns, however, they are still important for tastiness of water and provides further understanding on possible sources of pollution. As shown in Tables 1 and 2 all the wells and boreholes had conductivity and total dissolved solids within acceptable WHO range of 0.0005 to $0.05 \mathrm{~S} / \mathrm{m}$ and 1500 $\mathrm{mg} / \mathrm{l}$ respectively (Anon, 2010). Eighty five percent $(85 \%)$ of the samples had acceptable values for suspended solids and there seemed to be parity 


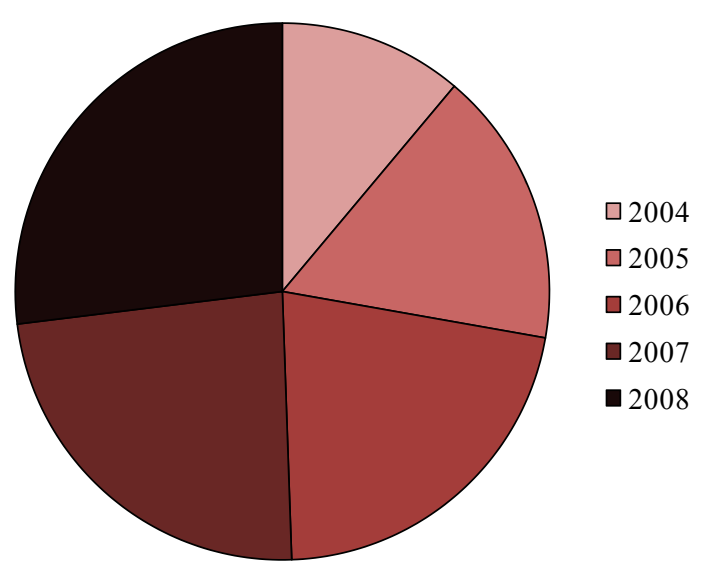

Fig. 5 Prevalence of Diarrhoea in Tarkwa Nsuaem and Prestea Huni-Valley Dis tricts

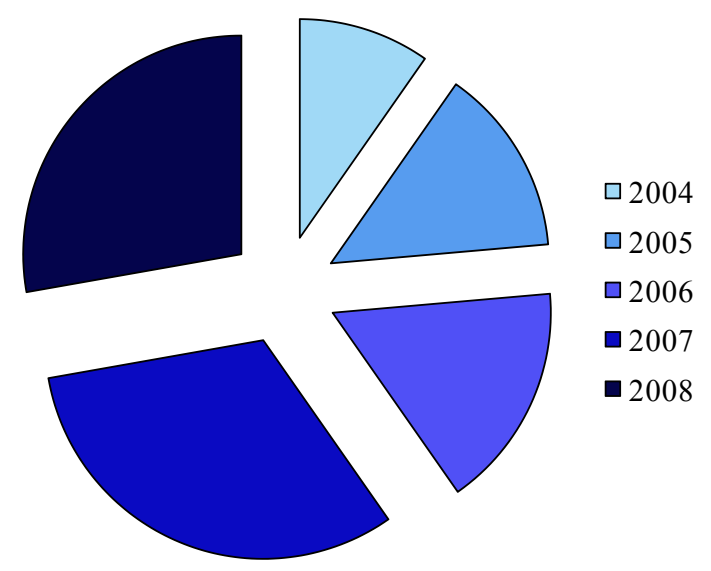

Fig. 6 Water Borne Disease Related Death Cases in Tarkwa Nsuaem Municipality and Prestea Huni Valley Districts during 2004 to 2008

between samples with high suspended solids and high turbidity values. The relatively high turbidity values may be linked to how water is fetched from the wells as that momentarily suspends particles.

The $\mathrm{pH}$ range of the wells and boreholes sampled are 4.2 and 7.1 though the WHO range of $\mathrm{pH}$ for drinking water is $6.5-8.5$. The average $\mathrm{pH}$ was 6.0 and about $55 \%$ of the samples had $\mathrm{pH}$ below 6.0. Areas with low $\mathrm{pH}$ values of 4.2 and 4.7 , Tamso and Jerusalem respectively, are close to each other and the causative agents could be similar. Mining areas with sulphur containing rocks, such as the study area, impact on the $\mathrm{pH}$ of groundwater and may give indications of exposed sulphide minerals in the community or problems with waste impoundments in neighbouring mining companies. The authorities concerned may con- sider lime treatment of wells and boreholes to cause neutralization and $\mathrm{pH}$ increase.

\subsection{Hydrogeological Modelling}

Mineral reactivity is estimated from the Saturation Index (SI) of the mineral under investigation (Deutsch, 1997). Saturation index is the logarithm of the ratio of the ion activity product to the solubility product. When the SI value of the species is positive it is oversaturated and therefore the mineral will tend to precipitate. The rate of precipitation is high if the SI value is high. On the other hand, undersaturation occurs when the SI value is negative, in which case the species do not precipitate but remain dissolved in solution. When the SI value is zero, then the mineral is in equilibrium with the water (Langmuir, 1997).

From the hydrochemical modelling conducted with PHREEQC, the highest saturation indices were obtained for goethite, hematite and ferric hydroxide in Dumasi at 7.38, 16.78 and 1.38 respectively. Other units that showed oversaturation of these iron compounds are Huni-Valley, Simpa, Aboso and Bepo wells. The high saturation indices of the iron oxides and hydroxides in the Dumasi samples explain the reddish brown precipitate formed when the samples are allowed to stand for a while. Other minerals such as sphalerite, pyrolusite, gypsum, cerrusite, and others, were undersaturated.

The saturation index (SI) values also indicate that gibbsite, Ca-montmorillonite, kaolinite, hematite and goethite, which are oxides or hydroxides of aluminium and silicon and, iron respectively, are oversaturated in Benso, Bonsa and Samahu wells and therefore can precipitate.

\section{Major Sources of Water Pollution in the Study Area}

In a mining area such as the one investigated, ground water pollution is usually attributed to mining operations. However, the study shows that community related activities had a great impact on the level of pollution and contamination of the hand dug wells and bore-holes. Some wells have cracked collars and are not covered. Since wells are generally low lying these create conditions for contamination by run-off or seepage of waste water. In addition, the shallow nature of some wells and proximity to sewage/waste disposal sites and cesspits contribute to the level of pollution (Kuma and Ewusi, 2009). Furthermore indiscriminate disposal of liquid waste into water bodies increase contamination due to the interaction of shallow water with surface water especially during rainy seasons. In future, siting of cesspits and wells/ boreholes may require a thorough site investigation to avoid contamination. 
Geological and mining activities also contributed to loss of water quality. The relatively high concentration of metals such as iron and manganese can be attributed to the iron rich minerals in the rocks and the manganese deposits of the area. In addition, mining exposes the rocks and these metals may be leached and deposited in water bodies. The use of manganese ore waste in road construction in sections of the study area has increased the exposure and availability of manganese which is now impacting ground water quality. Mercury can be directly attributed to small-scale gold mining.

Though lead minerals such as cerrusite $\left(\mathrm{PbCO}_{3}\right)$ and galena $(\mathrm{PbS})$ are present in the rocks within the area (Kesse, 1985) the indiscriminate disposal of dry cell batteries that are used for illumination purposes by artisanal and small-scale miners contributes to water pollution by lead. In addition to lead, these dry cell batteries may contain mercury, nickel and cadmium. Natural weathering and/or their synergistic interactions also contribute to the water quality. For instance oxidation of pyrite to ferrous or ferric sulphate could be the cause of high iron in the Dumasi bore water.

\section{Conclusions}

The physical, chemical and biological characteristics of water in 61 boreholes and wells in the Tarkwa-Nsuaem Municipality and the PresteaHuni-Valley District have been studied. The major metal pollutants observed and their peak concentrations were iron, manganese, molybdenum, lead, and mercury are of concern for the drinking water sources. In Akoon and Brenu Akyim, the high nitrate levels without bacterial pollution gives a lead that residual nitrates from blasting operations may be responsible as the two communities are close to active large scale mines where ammonium nitrate is a major constituent of the explosives.

Most of the wells and the boreholes at Tarkwa Community Centre, GAG Mile 7 No 2, Teberebie Roadside, Samahu Quarters, Dumasi, Abekoase, and Prestea Anyinam will require shock chlorination due to high microbial contamination. Such a step can potentially reduce the numerous domestic water related sicknesses recorded in the study area.

Hydrochemical modelling using PHREEQC software indicated that the Saturation Indices for goethite, hematite and ferric hydroxide were high in Dumasi at $7.38,16.78$ and 1.38 respectively. Other units that showed oversaturation of these iron compounds are Huni-Valley, Simpa, Aboso and Bepo wells. The relatively high saturation indices of the iron oxides and hydroxides in the Dumasi samples explains the reddish brown precipitate formed when the samples are allowed to stand for a while.

The contaminants identified may be attributed to geological, mining and non-mining community related activities. With continual increase in population and expansion of mining operations, it is necessary for water quality investigations to be conducted over an extended period and on a continuous basis. This will help in understanding the sources of the groundwater pollutants and the contribution of each to the water quality.

\section{Acknowledgements}

The authors wish to acknowledge the help of Dr Joanna Skluzacek, NSF Discovery Corps Fellow, Materials Research Science and Engineering Centre, Pennsylvania State University for her help with supplies for the study. Discussions with Dr S A Ndur of the University of Mines and Technology, Tarkwa are gratefully acknowledged.

\section{References}

Adimado, A. A., and Baah, D. A. (2002), "Mercury in human blood, urine, hair, nail, and fish from the Ankobra and Tano river basins in Southwestern Ghana", Bulletin of Environmental Contamination and Toxicology, Vol. 68, pp. 339-346.

Akabzaa, T. and Darimani, A. (2001), "Impact of Mining Sector Investment in Ghana: A Study of the Tarkwa Mining Region", Draft Report Prepared for Structural Adjustment Participatory Review International Network (SAPRIN), Washington, D C, www.natural-resources.org/ $\underline{\text { minerals/africa/docs/pdfs. }}$.

Al-Hassan, S. (2007), "A comparative study of rainfall pattern in the Tarkwa mining district of Ghana", Ghana Mining Journal, pp. 33-37.

Anon. (2010), "Water Treatment and Purification", www.lenntech.com/applications.

Anon. (2008), “Wassa West District Assembly Profile", Media Captain, Tarkwa, 3 pp.

Anon. (2004), "Guidelines for Drinking Water Quality", World Health Organization, www.who.int/topics/drinking water.

Anon. (1999), "DR/890 Datalogging Colorimeter Handbook", Hach Company, USA, pp. 203-230, 547-598.

Anon. (1996), “Guidelines for drinking-water quality, 2nd Ed., Vol. 2. Health criteria and other supporting information. World Health Organization, www.who.int/topics/ drinking_water.

Asante, K. A., Agusa, T., Subramanian, A., AnsaAsare, O. D., Biney, C. A., Tanabe, S. (2007), "Contamination status of arsenic and other trace elements in drinking water and residents from Tarkwa, a historic mining township in Ghana", Chemosphere Vol. 66, pp. 1513-1522.

Asklund, R. and Eldvall, B. (2005), "Contamination of Water Resources in Tarkwa Mining Area of 
Ghana", Department of Engineering Geology, Lund University Technology, Lund-Sweden, pp. 7 - 20.

Bamforth, S. M., Manning, D. A. C., Singleton, I., Younger, P. L., Johnson, K. L. (2006), "Manganese removal from mine waters - investigating the occurrence and importance of manganese carbonates, Applied Geochemistry", Vol. 21, pp. 1274-1287.

Barcelona, M., Gibbs, J. P., Helfrich, J. A. and Garske, E. E. (1985), Practical Guide for Groundwater Sampling, Illinois State Water Survey ISWS, Contract Report 374, 94 pp.

Bonzongo, J. C., Donkor, A. K., Nartey, V. K. (2003), "Environmental impacts of mercury related to artisanal gold mining in Ghana", Journal de Physique, Vol. 107, pp. 217-220.

Chappell, W. R., Meglen, R. R., Moure-Eraso, R., Solomons, C. C., Tsongas, T. A., Walravens, P. A. and Winston, P. W. (1979), "Human health effects of molybdenum in drinking water", U. S. Environmental Protection Agency, Rep. 600/179-006, $101 \mathrm{pp}$.

Claasen, H. C. (1982), "Guidelines and Techniques for Obtaining Water Samples that accurately represent the water quality for an aquifer", U.S Geological Survey Open File Report 82-1024, 49 pp.

Deutsch, W. J. (1997), "Groundwater Geochemistry: Fundamentals and Applications to Contamination", CRC Press, London, 232 pp.

Donkor, A. K., Bonzongo, J. C., Nartey, V. K., Adotey, D. K. (2006), "Mercury in different environmental compartments of the Pra River Basin, Ghana", Science of the Total Environment, Vol. 368, pp. 164-176.

Golow, A. A. and Kwaansaansah, E. E. (1994), "Comparison of Lead and Zinc Levels in the Hair of Pupils from 4 Towns in the Kumasi Municipal Area of Ghana", Bulletin of Environmental Contamination and Toxicology, Vol. 53, pp. 325-331.

Golow, A. A. and Laryea, J. N. (1994), "Levels of Iron, Silver, Zinc, and Lead in Oranges and Avocados from 2 Gold-Rich Towns Compared with Levels in An Adjacent Gold-Deficient Town", Bulletin of Environmental Contamination and Toxicology, Vol. 53, pp. 332-336.

Hafeman, D., Factor-Litvak, P., Cheng, Z. Q., van Geen, A., Ahsan, H. (2007), "Association between manganese exposure through drinking water and infant mortality in Bangladesh", Environmental Health Perspectives, Vol. 115, pp. 1107-1112.

Henry, J. and Heinke, W. (1996), "Environmental Science and Engineering", Princet and Hall UK London, 2nd Edition, 327 pp.

Holmes, S. (1996), "South Africa Water Quality Guidelines, Second Edition, Volume 1: Domes- tic Use", Department of Water Affairs and Forestry, pp. 2, 66 - 70, $144-156$.

Kesse, G. O. (1985), "The Mineral and Rock Resources of Ghana", Balkema, Netherlands, 610 pp.

Kortatsi, B. K. (2004), "Hydrochemistry of groundwater in the mining area of Tarkwa-Prestea, Ghana", PhD Thesis, University of Ghana, pp. 9 -35 .

Kuma, J. S. and Ewusi, A. (2009), Water resources issues in the Tarkwa Municipality, Ghana Mining Journal, Vol. 11, pp. 37-46.

Kuma, J. S. (2004), "Is groundwater in the Tarkwa gold mining district of Ghana potable?", Environmental Geology, Vol. 45, pp. 391-400.

Langmuir, D. (1997), “Aqueous Environmental Geochemistry”, Prentice-Hall, NJ, USA, pp. 78.

Momade, F. W. Y. and Darabor, G. A. S. (2007), "Preliminary studies on the water quality of the active areas of the Ashanti gold belt", The First International Conference on Environmental Research, Technology and Policy, (ERTEP), Preprint Number B2.17, 13 pp.

Sandaare, R. (2008), "Borehole/Well Water Quality Analysis Of the peripheral Mining Communities of Gold Fields Ghana Limited", Tarkwa Gold Mine, 45 pp.

Shaw, E. M. (1994), "Hydrology in Practice", Chapman and Hall, UK, pp. 160 - 162.

Todd, D. K. (1980), "Ground Water Hydrology", John Wiley and Sons Inc, NY, USA, 552 pp.

\section{Authors}

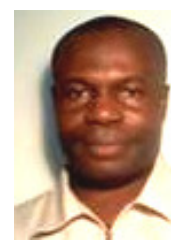

I. F. Quansah holds a Master of Science (MSc) degree in Mineral Engineering from the University of Mines and Technology, Tarkwa, Ghana. He is the Operations Manager - Mines of Sud-Chemie Water and Process Technologies, Ghana, which currently operates through Hanisa Industrial Support Services, its Ghana agent. Isaac has a vast knowledge in total water treatment and gold processing, having also worked as a Water Service Engineer at Medex Technical Services; Graduate Trainee Metallurgist at Aboso Goldfields; and as a Laboratory Supervisor at Ghana Manganese Company and Bayfields Laboratory Services, all in Ghana.

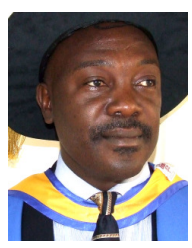

Richard K. Amankwah is currently an Associate Professor at the University of Mines and Technology, Tarkwa. He was educated at the Kwame Nkrumah University of Science and Technology (KNUST), Ghana, Technical University of Clausthal, Germany and Queen's University, Canada where he obtained his $\mathrm{PhD}$ in 2005. Richard has ample experience in mineral processing and extractive metallurgy, acquired through both academic research and industrial consulting activities. His current research areas include biohydrometallurgy, environmental biotechnology, microwaves in extractive metallurgy, gold beneficiation and small-scale mining. He is a member of the American Institute of Mining, Metallurgical and Petroleum Engineers, Inc. (SME). 